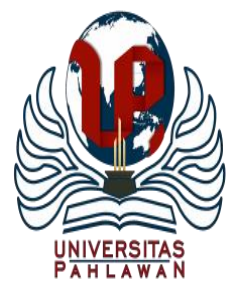

Jurnal Abdidas Volume 1 Nomor 5 Tahun 2020 Halaman 385 - 393

JURNAL ABDIDAS

Community Development Service on Educational and Health Sciences http://abdidas.org/index.php/abdidas

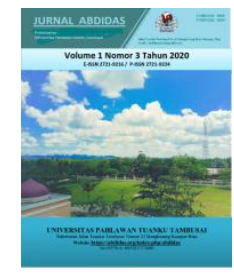

\title{
Pemberdayaan Masyarakat melalui Pengembangan Desain Produk Kerajinan Gerabah Galogandang Kabupaten Tanah Datar
}

\author{
Wisnu Prastawa ${ }^{1}$, Febri Yulika ${ }^{2}$, Taufik Akbar ${ }^{3}$ \\ Prodi Kriya Seni Institut Seni Indonesia Padangpanjang, Indonesia ${ }^{1}$, \\ Prodi Antropologi Budaya Institut Seni Indonesia Padangpanjang, Indonesia ${ }^{2}$, \\ Prodi Kriya Seni Institut Seni Indonesia Padangpanjang, Indonesia ${ }^{3}$ \\ E-mail : lempungart@yahoo.com ${ }^{1}$ febriyulikaisi@isi-padangpanjang.ac.id ${ }^{2} \underline{\text { taufik723@gmail.com }^{3}}$
}

\begin{abstract}
Abstrak
Galogandang merupakan sebuah desa di Kabupaten Tanah Datar, Sumatera Barat. Hampir sebagian besar penduduknya bekerja sebagai petani dan pengrajin gerabah. Jenis gerabah yang diproduksi terdiri dari periuk, vas dan celengan. Keberadaan kerajinan gerabah di Galogandang dikarenakan potensi tanah liat yang ada di daerah tersebut serta keterampilan masyarakat setempat. Meskipun begitu, desain produk gerabah yang dihasilkan sangat monoton dan sederhana. Guna mewujudkan pengembangan desain dan peningkatan kualitas gerabah Jorong Galogandang tersebut, salah satu usahan yang dapat dilakukan adalah melalui kegiatan pengabdian masyarakat berbasis Kuliah Kerja Nyata $(\mathrm{KKN})$. Kegiatan ini dilakukan oleh mahasiswamahasiswa seni Institut Seni Indonesia Padangpanjang dengan cara pelatihan keterampilan dalam bidang seni dan desain gerabah kepada masyarakat pengrajin setempat. Selain bermanfaat bagi pengrajin gerabah lokal, program KKN ini juga membantu mahasiswa mampu bersosialisasi di tengah-tengah masyarakat umum untuk mengaplikasikan ilmu dan keterampilan yang diperoleh di perguruan tinggi kepada masyarakat luas.
\end{abstract}

Kata kunci: pengabdian masyarakat, desain, produk, gerabah, Galogandang

\begin{abstract}
Galogandang is a village in Tanah Datar District, West Sumatera. Most of the population are farmers and pottery craftsman. The kind of pottery are producted consist of; pot, vasses and piggy bank. The existence of pottery in Galogandang because of potential clays in the village and skills the community. Even thought, it design of product very common and simple. In order to realize of development of design and quality improvement of Galogandang Pottery,one of those efforts is by community service program. This program is carried of by art studens of Indonesian Institute of The Arts Padangpanjang through skills training in field of art and design pottery to the craftmants in there. Besides providing benefits to local pottery craftmans, this community service program also helps studests to able to sosialize in public to apply of knowledge and skills acquired in college to wider community.
\end{abstract}

Keywords: community service program, design, product, pottery, Galogandang

Copyright (c) 2020 Wisnu Prastawa, Febri Yulika, Taufik Akbar

$\triangle$ Corresponding author

Address : Institut Seni Indonesia, Padang Panjang

Email : taufik723@gmail.com

Phone : 085292881636

(Media Cetak)

DOI : https://doi.org/10.31004/abdidas.v1i5.86 


\section{PENDAHULUAN}

Jorong Galogandang merupakan salah satu jorong yang ada di Nagari III Koto dalam Kecamatan Rambatan, Kabupaten Tanah Datar, provinsi Sumatera Barat. Secara geografis Jorong Galogandang terletak pada bagian Barat Daya dari Kecamatan Rambatan, berbatasan langsung dengan Kecamatan Pariangan dan Kecamatan Batipuah. Jorong Galogandang terletak pada ketinggian 540 meter di atas permukaan laut dengan luas wilayah sekitar 350 hektar. Sebagian besar daerah ini merupakan daerah perbukitan dan lembah, yang menyebabkan jalur penghubung antar wilayah melalui lembah dan perbukitan.

Sentra-sentra kerajinan gerabah di Sumatera Barat, umumnya terdapat di daerah pedesaan, di mana bahan baku berupa tanah liat cukup tersedia, demikan juga bahan penunjang lainnya yang mendukung proses produksi. Seni kerajinan gerabah di daerah Sumatera Barat terdapat di daerah Sungai Janiah di Kabupaten Agam, Galogandang di Kabupaten Tanah Datar, Sulik Aie di Kabupaten Solok, Sawah Lunto, Balai Talang, dan Galogandang di Kabupaten Lima Puluh Kota (Adirozal, 2001: 4). Dari daerah-daerah tersebut yang masih terus berproduksi sampai sekarang adalah seni kerajinan gerabah Jorong Galogandang, Kecamatan Rambatan di Kabupaten Tanah Datar.

Sejarah atau asal usul adanya seni kerajinan gerabah di Jorong Galogandang merupakan sesuatu yang juga sulit untuk diketahui secara otentik. Satu hal yang pasti, bahwa masyarakat di sana telah melaksanakan pekerjaan membuat gerabah yang diterima secara turun temurun.
Menurut Usria Dhavida (1979 : 7) bahwa keterampilan kriya tradisional -sebagaimana halnya kerajinan gerabah- didapat melalui proses sosialisasi dari generasi ke generasi secara informal, dengan memanfaatkan bahan baku yang didapat dari alam sekitarnya, dan proses pembuatannya mengandalkan tangan serta alat-alat sederhana, yang dikerjakan dalam lingkungan rumah tangga.

Seni kerajinan gerabah adalah karya seni yang unik, dan karakteristiknya mengandung muatan nilai-nilai yang kompleks, serta mendalam yang menyangkut nilai estetik, simbolik, filosofis, dan fungsional (Gustami, 1992: 71). Secara lebih khusus kemampuan para pengrajin gerabah untuk tetap bertahan dikarenakan mempunyai kekuatan, esensinya sebagai seni kerajinan yang sederhana, mempunyai kegunaan dalam arti benda pakai yang memberikan kepuasan kepada pembuat dan pelayanan kepada pemakainya (Astuti, 1997: 1).

Hampir semua pengrajin di Jorong Galogandang mengakui bahwa orang tua mereka terutama ibu, neneknya adalah pengrajin gerabah dahulunya. Dari merekalah kepandaian membuat gerabah itu diperoleh. Para pengrajin beranggapan bahwa seni kerajinan gerabah merupakan bagian dari budaya mereka yang masih hidup sampai saat ini. Artinya nenek moyang mereka sebelumnya telah membuat gerabah dan mewariskan pada generasi berikutnya sampai sekarang. Persoalan mengenai asal mula seni kerajinan gerabah pada umumnya tidak ada yang mengetahui.

Perkembangan seni kerajinan gerabah di Jorong galogandang memang belum sebaik di daerah lain di Indonesia. Hal ini disebabkan oleh 
berbagai faktor, seperti desain, teknik, kualitas produk, pemasaran, sumber daya manusia, dan lainnya. Meski didukung oleh ketersediaan bahan baku (tanah liat) yang banyak, tidak menjamin kelangsungan usaha kerajinan gerabah di daerah ini. Dalam hal ini Subroto (1991: 187) menjelaskan, bahwa ada lima faktor utama yang dapat membuat gerabah tetap tumbuh dan berkembang, yakni; kebutuhan, bahan, teknologi, modal, dan daya kreasi pengrajin.

Selain itu, persoalan pemasaran yang dilakukan oleh para pengrajin gerabah di galogandang selama ini adalah melalui pengepul, yang datang menjemput barang ke lokasi pembuatan gerabah, dengan harga yang cenderung lebih rendah. Pengepul ini kemudian melanjutkan distribusi ke pasar lokal maupun keluar daerah, seperti Batam, Tanjung Pinang, Pekan Baru, Jambi, bahkan sampai ke Malaysia dan Singapura. Melalui sistim ini yang lebih diuntungkan adalah pihak pengepul, karena bisa menjual dengan harga yang jauh lebih tinggi dari harga pembelian melalui para pengrajin.

Melihat potensi yang ada tersebut dan berdasarkan kondisi saat sekarang ini, diperlukan berbagai upaya dan terobosan, seperti dengan pemanfaatan teknologi dalam meningkatkan kualitas produk, desain, dan teknik, guna mensejajarkan perkembangannya dengan gerabah hasil produksi pabrik yang lebih efektif dan efesien. Setidaknya dengan mengedepankan nilai "craft"-nya dan unsur dekorasinya. Memang diakui bahwa keahlian dalam membuat gerabah masyarakat Galogandang tidak diragukan lagi, namun di dalam pengembangan bentuk produk sangat minim. Maka dari itu untuk meningkatkan pendapatan masyarakat Galogandang perlu dilakukan pemberdayaan kepada masyarakat berupa pengembangan desain dan diversifikasi produk kerajinan gerabah dalam bentuk cenderamata, sekaligus hal ini dapat menunjang pariwisata yang ada di Kecamatan Rambatan dan Kabupaten Tanah Datar umumnya.

Dalam rangka mewujudkan peningkatan kualitas, pengembangan desain dan diversifikasi produk kerajinan gerabah masyarakat Jorong Galogandang tersebut, maka kegiatan KKN-PPM sebagai implementasi dari pengabdian kepada masyarakat, diharapkan dapat memecahkan masalah yang dihadapi oleh masyarakat pengrajin. Melalui kegiatan KKN-PPM, dapat kiranya dilakukan usaha pemberdayaan masyarakat perajin gerabah baik dalam bentuk peningkatan motivasi, menggerakkan masyarakat serta melakukan tindakan pendampingan. Kegiatan tersebut membutuhkan sentuhan teknologi, serta pendekatan sosial yang sesuai dengan kebutuhan dan kondisi masyarakat.

Dengan kegiatan tersebut mahasiswa yang telah mempunyai bekal ilmu tentang kriya keramik dan pengembangan desain produk, manajemen pemasaran, serta bidang ilmu yang relevan lainnya mendapat kesempatan untuk mentransfer ilmu yang telah diperoleh di perkuliahan kepada masyarakat. Di samping itu mahasiswa juga belajar bagaimana bersosialisasi di tengah masyarakat, sehingga mereka mendapat bekal pengalaman dalam memecahkan permasalahan masyarakat. 
Pelaksanaan kegiatan KKN-PPM di jorong Galogandang ini akan bersinergi dengan mitra Pemerintah Daerah yaitu Dinas Koperasi Perindustrian dan Perdagangan (KOPERINDAG) Kabupaten Tanah Datar. Pemilihan mitra ini didasarkan pada tupoksinya sebagai regulator dan institusi pembina Industri Kecil Menengah (IKM), termasuk industri kerajinan Gerabah. Selain itu mitra KOPERINDAG juga memiliki komitmen dalam pendampingan berbagai kegiatan pelatihan terhadap IKM yang ada di kabupaten Tanah Datar, mulai dari tahap penganggaran, pembinaan, penyuluhan dan promosi produk dalam berbagai event. Terkait dengan kegiatan KKN-PPM di Jorong Galogandang ini, KOPERINDAG sebagai mitra juga memiliki komitmen kesediaan dana pendamping secara in cash dan in kind dalam bentuk program kerja bersama untuk membantu pelaksanaan kegiatan selama program KKN-PPM berlangsung serta memberikan pembinaan dan penyuluhan pada IKM gerabah di Jorong Galogandang, baik dalam pelaksanaan program KKN-PPM maupun kegiatan dan rencana tindak lanjut.

\section{METODE}

\section{Persiapan}

Persiapan yang dilakukan meliputi rekrutmen mahasiswa, koordinasi dengan pelaksana KKN ISI Padangpanjang, serta dengan Pemerintah Kabupaten Tanah Datar. Mahasiswa direkrut melalui surat penawaran kepada Pembantu Dekan bidang akademik di lingkungan ISI Padangpanjang. Mahasiswa yang mendaftar diseleksi berdasarkan persyaratan akademik, relevansi bidang ilmu dengan program sasaran, motivasi serta sikap dan karakter mahasiswa. Persyaratan akademik dan bidang ilmu diseleksi melalui adminstrasi, sedangkan motivasi, sikap dan karakter mahasiswa diseleksi melalui interview. Pada tahapan persiapan ini, tim pelaksana melakukan survey lokasi pelaksanaan KKN-PPM yang telah di tetapkan. Survey tersebut dilakukan dengan meninjau dan melihat secara dekat lingkungan masyarakt dan aktifitas sehari hari masyarakat Jorong galogandang Nagri III Koto serta potensi daerah khususnya terkait dengan seni kerjinan gerabah di jorong Galogandang tersebut. Hasil survei menetapkan Jorong Galogandang sebagai tempat Pelaksanaan KKN-PPM.

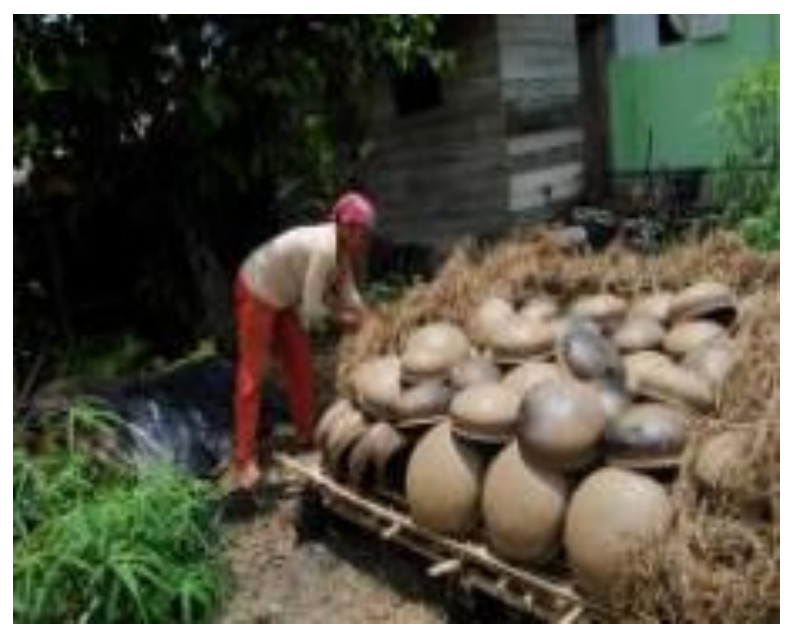

Gambar 1. Aktifitas Warga Galogandang

Tindak lanjut dari penetapan lokasi pelaksanaan kegiatan KKN PPM, tim pelaksana melakukan proses perizinan secara administratif. Perizinan dimulai dari penandatanganan kerjasama dengan Nagari III Koto, surat kerjasama dan Dukungan dari Dinas Koperindag Tanah Datar serta ijin KKN dari Kesbangpol Tanah datar 
dengan tembusan Kepada Bupati Tanah Datar, Dandim 0307 Tanah Datar, Kapolres Tanah Datar, Kepala Dinas Koperindag Tanah Datar, Ketua LPPMPP ISI Padangpanjang, Camat Rambatan, Wali Nagari III Koto dan Wali Jorong Galogandang. Setelah ditetapkannya lokasi dilakukan Pembekalan KKN-PPM dan Pelepasan Peserta KKN-PPM.

Tahapan Pembekalan KKN-PPM dilaksanakan 3 tahap dengan rincian kegiatan tahap pertama adalah pembekalan KKN-PPM Umum bersama dengan KKN Reguler ISI Padangpanjang. Mahasiswa dibekali dengan materi etika dan sosiologi masyarakat pedesaan. Materi ini bertujuan supaya mahasiswa peserta dapat memelihara hubungan baik, hidup rukun, serta cepat dalam bersosialisasi dengan masyarakat dilapangan serta peka terhadap situasi dan kondisi masyarakat yang memang berbeda dengan kondisi sosial akademis seperti yang mahasiswa jalani sehari hari.

Dalam pembekalan ini mahasiswa juga dibekali selama 2 hari pembekalan khusus KKNPPM Kemeristekdikti dengan materi yang terkait dengan Pengenalan Lokasi, Pengembangan Desain Gerabah serta pembetukan tim kerja. Mahasiswa yang lolos seleksi dibekali dengan kuliah pembekalan yang disampaikan oleh narasumber yang relevan dengan program serta oleh dosen pembimbing lapangan. Materi pembekalan meliputi:

- Ilmu tentang Keramik

- Ilmu Desain Produk

- Pembuatan Contoh Produk Gerabah

- Teknik Ornamen/Menghias
- Manajemen Pemasaran dan Promosi Produk

- Sosiologi Masyarakat Pedesaan

- Etika

\section{Pelaksanaan}

Program yang dilaksanakan antara lain pengembangan desain produk, teknik dekorasi, finishing pewarnaan. Metode yang digunakan dalam pelatihan diantaranya :

a. Ceramah; memberikan pengetahuan tentang ilmu desain cara pembuatan desain, dan bahan yang digunakan.

b. Demonstrasi; memperagakan secara langsung bagaimana membuat desain yang baik, membuat ornamen dengan teknik toreh serta finishing warna.

c. Praktek; peserta pelatihan mempraktekkan langsung bagaimana membuat desain dan mengembangkannya sehingga menjadi produk.

Kegiatan pelatihan dilaksanakan di Balai Adat Jorong Galogandang seminggu dua kali dan selama 4 minggu, serta setiap hari di home industri masing-masing di kirim sumber daya mahasiswa peserta KKN-PPM yang dibuat beberapa kelompok untuk pro aktif secara langsung memberikan pengarahan-pengarahan secara teknis untuk dapat mengembangkan desain dan teknik finishing. Kegiatan ini dilaksakanan pada 23 Juli 2018 sampai 25 Agustus 2018.

\section{HASIL DAN PEMBAHASAN}

Gerabah Galogandang merupakan hasil kerajinan tangan masyarakat galogandang yang pada umumnya adalah pengrajinya ibu-ibu. Produk 
yang dihasilkan berupa periuk belanga sebagai alat (wadah) air minum maupun sebagai lat memasak. Kerajinan tangan ini sudah turun temurun di lakukan oleh pengrajin Galogandang. Tetapi saat ini pelaku kerajinan ini makin lama makin menurun jumlahnya. Di Jorong atau dusun Galogandang tersebut hanya tinggal 10 titik pengrajin rumahan yang masih memproduksi gerabah. Seiring kurang minatnya generasi muda meneruskan kegiatan pembuatan gerabah ini. Sehingga usia pengrajin gerabah ini berkisar paling muda 40 tahun ke atas sampai 70 tahun yang masih mau menekuni kerajinan ini. Hal tersebut dikhawatirkan akan menyebabkan kepunahan potensi kerajinan ini. Masyarakat generasi muda lebih memilih pergi merantau mencari pekerjaan di kota besar seperti jakarta dan pulau jawa lainnya.

Hal ini mungkin sangat dipengaruhi oleh tidak berkembangnya kerajinan ini, baik dari segi desain, pemasaran serta inovasi kreatif lainnya.

Melihat kondisi tersebut sangat diperlukan pembinaan dan pengembangan kerajinan ini, upaya pengembangan ini dilakukan dengan program KKN PPM dengan tema Pemberdayaan Masyarakat Melalui Pengembangan Desain Produk Kerajinan Gerabah di Jorong Galogandang, Nagari III Koto, Kecamatan Rambatan Kabupaten Tanah Datar.
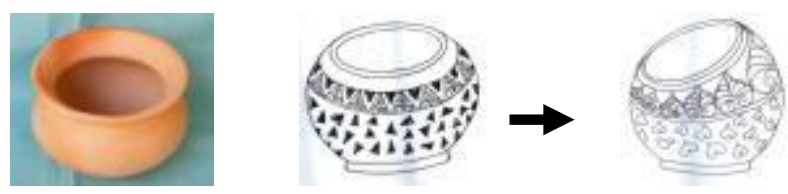

Gambar 2. Rencana pengembangan desain
Untuk menghasilkan produk gerabah Galogandang ada beberapa tahapan yang dilakukan yaitu sebagai berikut :

1. Proses pengolahan bahan baku tanah liat.

Bahan baku gerabah Galogandang diambil dari tanah sawah di sekitar jorong Galogandang. Tanah tersebut diolah dan dicampur dengan pasir halus. Proses pengolahan bahan tersebut dilakukan dengan cara manual yaitu dengan mengulet dengan tangan serta dipijak-pijak untuk meratakan campusan pasir dan tanah liat, serta meratakan keplastisan dan homogenitas tanah. Sehingga campuran bahan dasar tersebut menjadi padat dan bebas dari rongga udara.

2. Proses pembetukan

Proses pembetukan tanah liat ini dilakukan dengan teknik tokok atau dengan cara di pukul-pukul yang didalamnya diganjal dengan batu. Tekni ini sangat khas dan pengrajin sangat sulit untuk mengembangkan teknik-teknik pembentukan yang lain. Hal ini disebabkan karena memang dalam dunia keramik/ gerabah, karakter bahan sangat erat kaitanya dengan kesesuaian teknik pembetukan yang dilakukan. Masing masing jenis tanah liat mempunyai karakter keplastisan yang berbeda beda. Hal ini mungkin yang menyebabkan kurang bisa dikembangkannya suatu teknik dalam komuniatas pengrajin gerabah, tetapi hal ini pula yang menjadi keunikan gerabah dari berbagai daerah. Masing-masing mempunyai teknik yang khas di setiap daerah. Teknik yang ada di suaatu daerah belum tentu cocok 
DOI : https://doi.org/10.31004/abdidas.v1i5.86

diterapkan didaerah lain karena pada umumnya karakter tanah liat sangat menentukan kesesuaian teknik yang akan digunakan.

3. Proses pengeringan

Tanah liat sebelum didekorasi dan dibakar perlu adanya proses pengeringan. proses pengeringan ini adalah menghilangkan kadar air dalam badan gerabah, sehingga gerabah menjadi agak keras dan bisa dilakukan proses dekorasi dengan teknik gores. Tekni dekorasi ini sebelumnya belum ada dilakukan oleh pengrajin. Mereka hanya menjual produknya dengan polos tanpa dekorasi. Sehingga secara visual kurang menarik dan memang hanya mengejar fungsi pakai yaitu sebagai alat memasak.

4. Proses pembakaran

Proses pembakaran merupakan proses wajib dalam pembetukan gerabah. Tanpa dibakar belum bisa disebut gerabah dan memang benda tersebut belum bisa di gunakan. Tanah tersebut masih bisa hancur lagi terkena air jika belum dibakar. Proses pembakaran ini diperlukan guna menghilangkan air yang dalam badan tanah liat serta meleburkan atau melelehkan unsur kwarsa (Silica) dalam tanah liat sehingga tanah liat menjadi keras saat unsur silika tersebut meleleh dan didinginkan kembali setelah dibakar. Hal ini lah yang menyebabkan tanah liat tersebut tidak hancur kembali jika terkenaa air setelah melalui proses pembakaran.

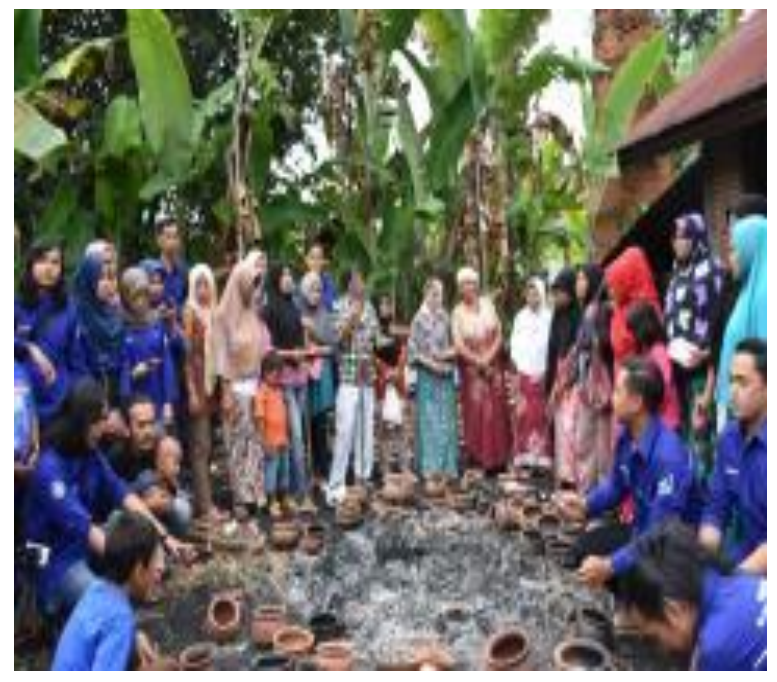

Gambar 3. Kegiatan pembakaran gerabah

5. Finishing dan pewarnaan

Proses ini sebelumnya belum pernah dilakukan oleh pengrajin. Proses ini merupakan program pokok pengembangan desain kerajinan KKN PPM ini. Sebelumnya hasil produk kerajinan gerabah Galogandang adalah gerabah polos dan hanya berfungsi sebagai alat memasak saja. Dengan dikembangkanya desain dan dekorasi, akan menambah nilai estetika maupun memperluas fungsi gerabah tersebut.

Sebelum dikembangkannya proses finishing dan pewarnaan, Gerabah Galogandang hanya bisa difungsikan menjadi alat memasak saja. Setelah melalui pengembangan desain dan finishing, Gerabah Galogandang dapat dikembangkan fungsinya menjadi vas table bouquet, pot hias, tempat buah dan lain lain. Hal ini tentunya merupakan terobosan baru untuk lebih mengembangkan hasil produk gerabah Galogandang. Dampaknya akan meningkatkan dari segi harga, produktifitas dan kesejahteraan masyarakat pengrajin Galogandang. 


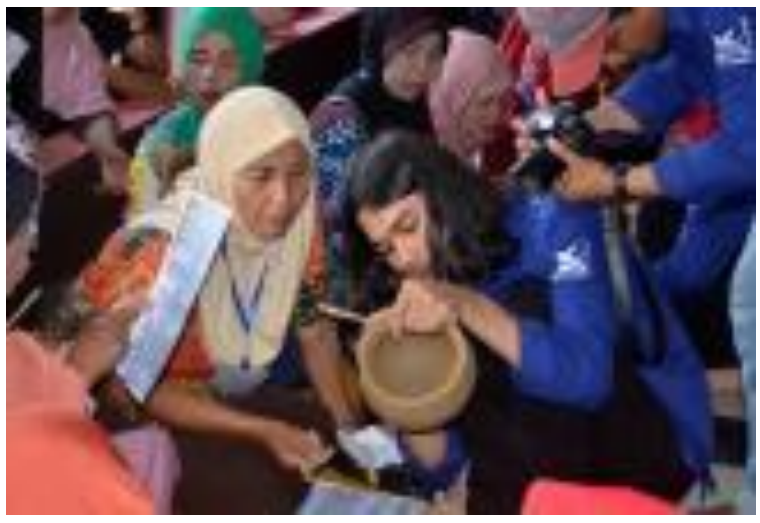

Gambar 4. Kegiatan Pelatihan Finishing Gerabah pada Masyarakat

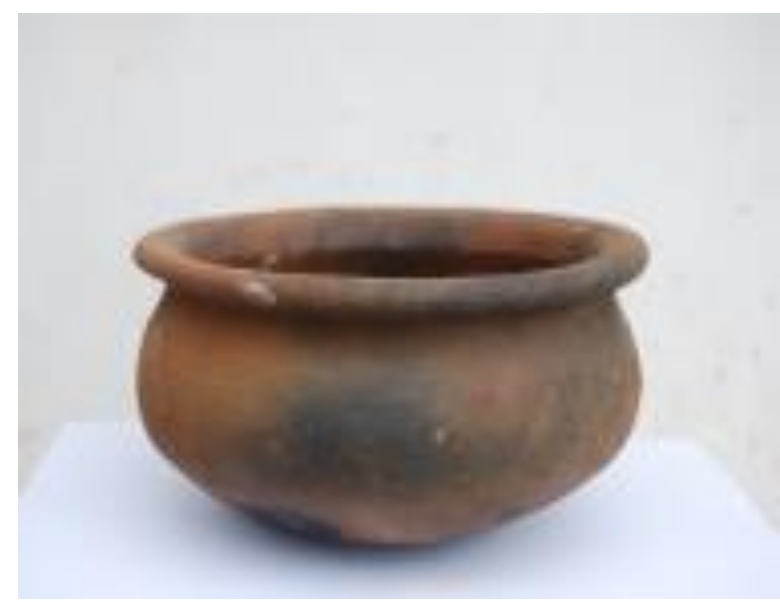

Gambar 5. Produk Awal Gerabah Galogandang

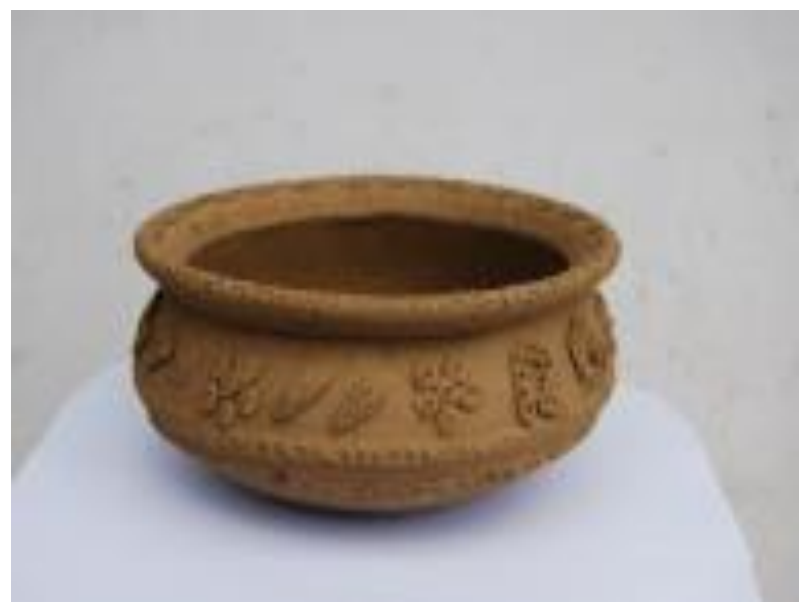

Gambar 6. Pengembangan Dekorasi 1

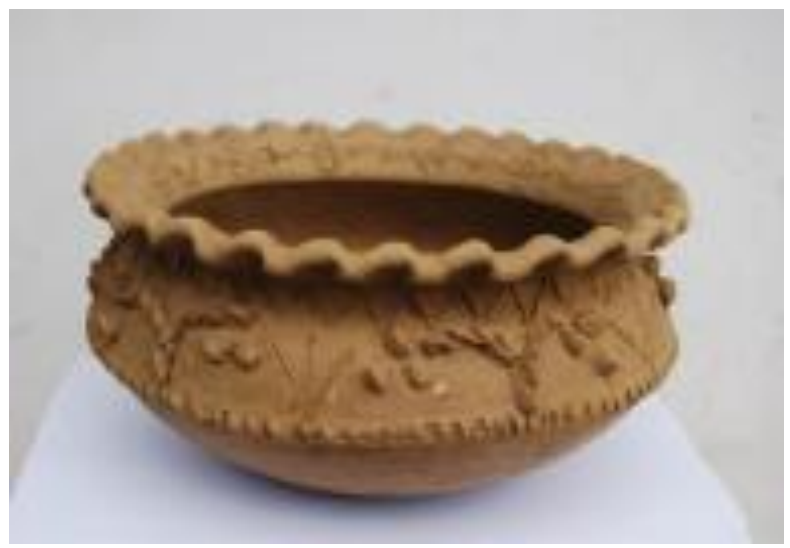

Gambar 7. Pengembangan Dekorasi 2

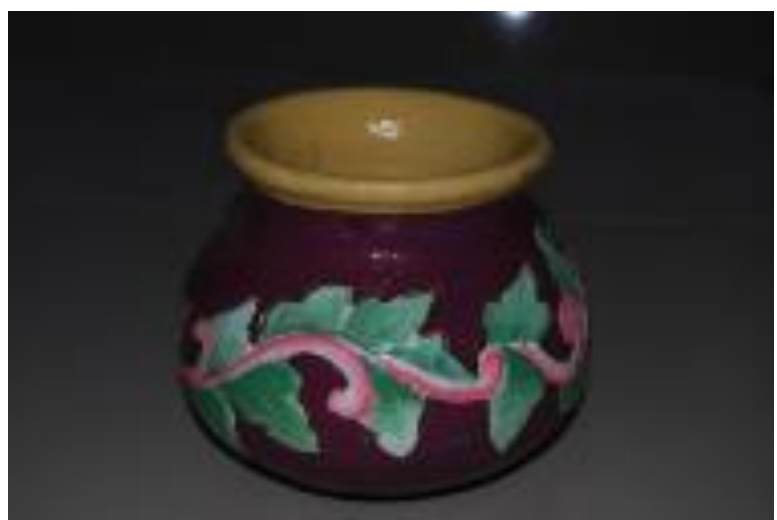

Gambar 8. Pengembangan Finishing Dan Warna 1

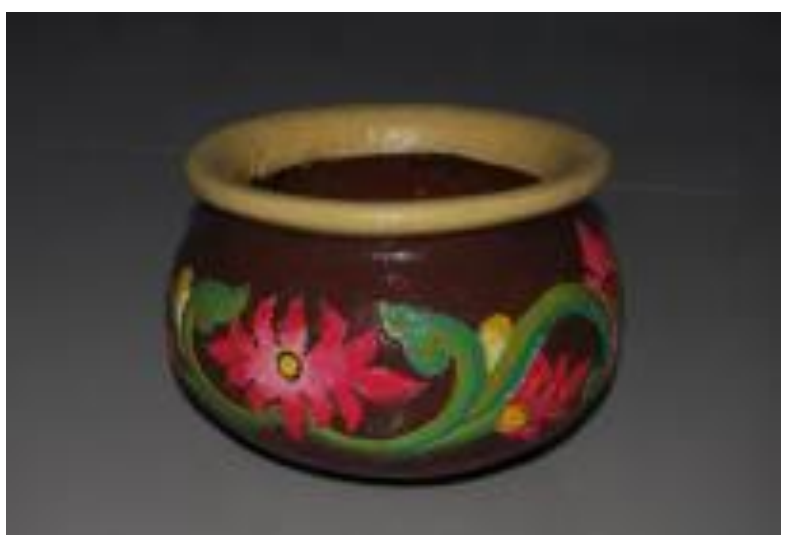

Gambar 9. Pengembangan Finishing Dan Warna 2

\section{SIMPULAN}

Dengan adanya peningkatan pengetahuan dan keterampilan masyarakat khususnya ibu-ibu pengrajin Gerabah, Melalui pelatihan dan pembinaan oleh mahasiswa peserta KKN-PPM, 
diharapkan program ini akan dilaksanakan berkesinambungan. Kelanjutan ini diharapkan atas kesadaran dan motivasi masyarakat dengan dukungan pemerintah daerah Tanah Datar. Kesadaran dan motivasi masyarakat tersebut akan muncul dengan adanya manfaat yang mereka peroleh dengan adanya program ini. Diantaranya adanya peningkatan produk gerabah baik secara kenatitatif maupun kualitatif. Berkaitan dengan pengembangan desain kerajianan gerabah untuk KKN-PPM ini dilakukan dengan pengembangan dekorasi dan finishing pewarnaan. Dimana masyarakat jorong Galogandang sudah bertahuntahun membuat periuk belanga tanpa pengembangan segi finishing. Oleh karena itu dengan adanya program KKN-PPM ini akan dilakukan sentuhan baru berupa pengembangan desain dan finishing. Sehingga nantinya bisa meningkatkan pendapatan masyarakat setempat dan pemasaran tidak hanya disekitar di lingkungan Jorong Galogandang dan pasar tradisional. Harapan kedepan produk ini menjadi produk unggulan Kabupaten Tanah Datar.

\section{DAFTAR PUSTAKA}

Adi Rozal, 2001,'Usaha Gerabah untuk Cinderamata dalam Pariwisata Sumatera Barat, Studi Kasus Usaha Gerabah di Andaleh kabupaten Lima Puluh Kota", Tesis, Universitas Udayana, Denpasar.

Ambar Astuti, 1997, “ Pengetahuan Keramik”, Gajah Mada University Press, Yogyakarta

Gustami SP, Saptoto dan Nano S, 1992," Filosofi Seni Kriya Tradisional Indonesia", Jurnal Pengetahuan dan Penciptaan Seni, II/01, BP. ISI Yogyakarta, Yogyakarta.

Subroto SM, 1991," Keramik sebagai Media Ekspresi Murni”, dalam Soedarso SP, (ed)
Beberapa Catatan Tentang Kesenian Kita, BP. ISI Yogyakarta, Yogyakarta.

Usri Dhavida, Dkk, 1979, Kerajinan Tradisional Anyaman Pandan di Sumatera Barat, Padang : Proyek Permusiuman Sumatera Barat. 